\title{
A single amino acid substitution in transmembrane helix VI results in overexpression of the human GnRH receptor
}

\author{
David B Myburgh, Adam J Pawson, James S Davidson, Colleen A Flanagan, Robert P Millar and \\ Janet P Hapgood \\ MRC Unit for Molecular Reproductive Endocrinology, Department of Chemical Pathology, University of Cape Town Medical School, Observatory, \\ 7925, South Africa
}

(Correspondence should be addressed to J P Hapgood who is now at Department of Biochemistry, University of Stellenbosch, Private Bag X1, Matieland, 7602, South Africa)

(C A Flanagan is now at Fishberg Center for Neurobiology, Box 1065, Mount Sinai School of Medicine, New York 10029-6574, USA)

\begin{abstract}
Objective: Construction of constitutively active mutants of the GnRH receptor, a member of the Gprotein coupled receptor superfamily, would facilitate investigation of the mechanism of receptor activation.

Design: Point mutations were introduced in the human GnRH receptor in positions corresponding to those which caused constitutive activity in other G-protein coupled receptors. The effects of these mutations on ligand binding, receptor intracellular signaling and receptor expression were determined. Methods: Wild type and mutated receptor cDNAs were expressed in COS-1 cells. Basal and agoniststimulated inositol phosphate production and ligand binding were determined. In addition, receptor mRNA levels, cell surface receptor stability and rate of internalization were measured.

Results and conclusions: Although none of the mutant receptors exhibited constitutive activity, mutation of Phe-272 in transmembrane helix VI to Leu increased cell surface receptor numbers, with unchanged affinities for radiolabeled agonist, superagonist and antagonist peptides compared with wild type receptor. The cell surface receptor stability and rate of internalization were similar for wild type and F272L GnRH receptors. Thus a single amino acid mutation in transmembrane helix VI causes an increase in cell surface receptor numbers, which appears to result from an increased rate of receptor protein translation, processing or insertion into membranes.
\end{abstract}

European Journal of Endocrinology $139438-447$

\section{Introduction}

Gonadotropin releasing-hormone (GnRH) is a decapeptide which exerts its biological effects via binding to and activating the GnRH receptor (GnRHR) on pituitary gonadotrope cells, to result in the release of the gonadotropins. The GnRHR (1-4), a member of the G-protein coupled receptor (GPCR) superfamily, which is characterized by seven putative transmembrane helices (TMHs), activates phospholipase $\mathrm{C}$ via coupling to the $\mathrm{G}_{\mathrm{q} / 11}$ class of G-proteins (5).

Some insight into the mechanism of receptor activation has emerged from site-directed mutagenesis of GPCRs $(6,7)$ and from naturally occurring mutations which cause constitutive activation (8-15). A common mechanism of activation may exist for all GPCRs, regardless of which of the G-proteins they couple to. Several different receptors which couple to different G-proteins have been constitutively activated by mutations in the C-terminal part of intracellular loop III (ICIII), and the middle to intracellular part of TMHs VI and VII $(7,9,12,15-21)$. However, studies on the thyroid-stimulating hormone (TSH) receptor (TSHR) indicate that stimulation of cAMP and phospholipase $\mathrm{C}$ dependent cascades may involve different conformational changes in the same receptor, and different intramolecular interactions (14). In addition, a comparison of mutants of the TSHR and luteinizing hormone receptor indicates that some wild type receptors may be less constrained than others in the inactive form, and thus more readily constitutively activated by point mutations $(11,14)$. The GnRHR has a number of unique structural features such as the absence of a C-terminal tail. This raises the question as to what extent GnRHR conforms to other members of the GPCR family in the role of apparently homologous amino acid residues.

We have systematically incorporated mutations in the GnRHR homologous to mutations which constitutively activate other GPCRs. We report here that none of the GnRHR mutants is constitutively active, although receptor function and/or expression levels are altered. Mutation of Phe at position 272 in TMH VI to Leu gives rise to increased receptor expression relative to the wild type receptor. 


\section{Materials and methods}

\section{Site-directed mutagenesis}

The human GnRHR cDNA (4) was cloned into the EcoRI/XhoI sites of the phagemid pBluescript II SK(Stratagene, La Jolla, CA, USA). Oligonucleotidedirected mutagenesis was performed using the method of Kunkel et al. (22). Products of the mutagenesis were used to transform competent XL-1 Blue E. coli. Plasmid DNA was extracted from ampicillin-resistant clones and sequenced using a Sequenase kit (United States Biochemical Corporation, Cleveland, OH, USA). Mutant cDNAs were subcloned into the EcoRI/XhoI sites of the mammalian expression vector pcDNAI/Amp (Invitrogen, Carlsbad, CA, USA). Two different F272L mutants were constructed, containing different codons for Leu, i.e. wild type: GCA TTT GCC, F272L-1: GCG CTA GCC and F272L-2: GCG CTT GCC, where TTT is the wild type codon for Phe. All the results shown in the figures and table were obtained with F272L-1.

\section{Transfection}

Plasmid DNA for transfection was prepared using Qiagen columns (Qiagen, Hilden, Germany) according to the manufacturer's instructions. COS-1 cells were cultured in Dulbecco's Modified Eagle's Medium (DMEM) (Gibco, Paisley, UK) containing 10\% fetal calf serum (Highveld Biological Pty Ltd, Lyndhurst, Gauteng, Republic of South Africa) in a $10 \% \mathrm{CO}_{2}$ atmosphere. Cells were seeded at $2 \times 10^{5}$ per well in poly-D-lysine coated 12 -well plates 1 day before transfection by a modified DEAE-dextran method (23). Cells were washed once with Hepes $(20 \mathrm{mmol} / \mathrm{l}$, pH 7.4) buffered DMEM and then incubated with $0.6 \mathrm{ml} /$ well serum-free DMEM containing $3.3 \mu \mathrm{g} / \mathrm{ml}$ plasmid DNA and $0.3 \mathrm{mg} / \mathrm{ml}$ DEAE-dextran for $4 \mathrm{~h}$ at $37^{\circ} \mathrm{C}$. The cells were incubated for a further $1 \mathrm{~h}$ at $37^{\circ} \mathrm{C}$ with DMEM containing $2 \%$ fetal calf serum and $200 \mu \mathrm{mol} / \mathrm{l}$ chloroquine, after which they were incubated in DMEM containing 10\% DMSO for $2 \mathrm{~min}$. The cells were then cultured overnight in DMEM with 10\% fetal calf serum. The cells were washed with Hepes DMEM after each step.

\section{Inositol phosphate (IP) production}

Twenty-four hours after transfection, cells were incubated overnight with $2 \mu \mathrm{Ci} / \mathrm{ml}$ myo-[2- $\left.{ }^{3} \mathrm{H}\right]$ inositol (Amersham, Bucks, UK) in $0.5 \mathrm{ml} /$ well Medium 199 (Gibco) containing 2\% fetal calf serum. Total IPs were then measured as previously described (24).

\section{Radioligand binding}

GnRH (pyroGlu-His-Trp-Ser-Tyr-Gly-Leu-Arg-Pro-Gly-NH $\mathrm{N}_{2}$ ) and GnRHA ([D-Ala ${ }^{6}-\mathrm{N}-\mathrm{Me}^{-\mathrm{Leu}^{7}}$,Pro $^{9}$-NHEt $\left.] \mathrm{GnRH}\right)$, a potent GnRH agonist, were synthesized by conventional solid phase synthesis. Ant26 ([Ac-D-p-ClPhe ${ }^{1}, \mathrm{D}-\mathrm{p}-\mathrm{ClPh} \mathrm{P}^{2}$, D-Trp ${ }^{3}, \mathrm{D}-\mathrm{Lys}^{6}{ }^{6} \mathrm{D}-\mathrm{Ala}^{10} \mathrm{NH}_{2}$ ] GnRH), a competitive GnRH antagonist, was a gift from D Coy (Department of Medicine, Tulane University School of Medicine, New Orleans, LA 70112, USA). Whole cell receptor ligand binding was performed to determine ligand affinities and receptor numbers. For agonist binding studies, transfected COS-1 cells were washed with cold Buffer I $(140 \mathrm{mmol} / \mathrm{l} \mathrm{NaCl}, 4 \mathrm{mmol} / \mathrm{l} \mathrm{KCl}, 20 \mathrm{mmol} / \mathrm{l}$ Hepes, $8 \mathrm{mmol} / \mathrm{l}$ glucose, $0.1 \%$ fatty acid-free BSA, $1 \mathrm{mmol} / \mathrm{l}$ $\mathrm{CaCl}_{2}, 1 \mathrm{mmol} / \mathrm{l} \mathrm{MgCl}_{2}, \mathrm{pH}$ 7.4) and then incubated for 3-4 h on ice in Buffer I containing 100000 c.p.m. ${ }^{125} \mathrm{I}-\mathrm{GnRHA}(50 \mathrm{pmol} / \mathrm{l})$ and varying concentrations of unlabeled GnRHA. Antagonist binding studies were performed at $37^{\circ} \mathrm{C}$, and cells were incubated for $1 \mathrm{~h}$ with 100000 c.p.m. ${ }^{125} \mathrm{I}-\mathrm{Ant} 26$ (50 pmol/l). In both agonist and antagonist assays, incubation was terminated by washing the cells in cold Buffer I containing $0.5 \%$ BSA. Cells were removed from the dishes with $0.1 \mathrm{~mol} / \mathrm{l} \mathrm{NaOH}$ at room temperature and their radioactivity counted in a scintillation counter. Non-specific binding was estimated by incubating untransfected cells with 100000 c.p.m. of the labeled ligand, in the absence of unlabeled ligand.

For membrane binding assays, transfected COS-1 cells were homogenized in binding buffer $(1 \mathrm{mmol} / \mathrm{l}$ Hepes, $0.1 \mathrm{mmol} / \mathrm{l}$ EDTA, $\mathrm{pH}$ 7.4) and centrifuged at $13000 \mathrm{~g}$ for $30 \mathrm{~min}$ at $4{ }^{\circ} \mathrm{C}$. For agonist binding, the crude membrane pellet was resuspended in binding buffer $\left(7.5 \times 10^{5}\right.$ cell equivalents/tube $)$ and incubated with 100000 c.p.m. ${ }^{125} \mathrm{I}-\mathrm{GnRHA}$ ( $50 \mathrm{pmol} / \mathrm{l}$ ), and varying concentrations of unlabeled GnRHA for $2 \mathrm{~h}$ on ice. For antagonist binding, homogenized COS-1 cells were centrifuged for $10 \mathrm{~min}$ at $1000 \mathrm{~g}$ at $4{ }^{\circ} \mathrm{C}$ to remove cell debris and nuclei, to reduce non-specific binding. The resulting supernatant was then centrifuged at $13000 \mathrm{~g}$ for $30 \mathrm{~min}$ at $4{ }^{\circ} \mathrm{C}$ as for the agonist binding assay. The resuspended membrane pellet was incubated with 100000 c.p.m. ${ }^{125} \mathrm{I}-\mathrm{Ant} 26$ (50 pmol/l), and varying concentrations of unlabeled Ant 26 for $30 \mathrm{~min}$ at $37^{\circ} \mathrm{C}$. Maximum binding of ${ }^{125} \mathrm{I}$-Ant26 was achieved after 15 min under these conditions and was stable for at least $1 \mathrm{~h}$. In both agonist and antagonist assays, the incubation was terminated by the addition of $3 \mathrm{ml}$ icecold $0.01 \%(\mathrm{w} / \mathrm{v})$ aqueous polyethylenimine (Sigma, St Louis, MO, USA) and immediate filtration through GF/C filters (Whatman, Maidstone, Kent, UK) which were presoaked in $1 \%(\mathrm{w} / \mathrm{v})$ polyethylenimine, followed by three washes with $3 \mathrm{ml} 0.01 \%$ polyethylenimine. Non-specific binding was estimated in the presence of $10^{-6} \mathrm{~mol} / \mathrm{l}$ unlabeled Ant26 for both agonist and antagonist binding assays. Non-specific binding of ${ }^{125}$ I-Ant26 ranged from 4000 to 7000 c.p.m. while maximum specific binding was 12000 to 16000 c.p.m. in the wild type GnRHR.

\section{Northern blot analysis}

Total RNA from COS- 1 cells was extracted $48 \mathrm{~h}$ after transfection according to the method of Chomczynski \& 
Sacchi (25). Twenty micrograms RNA were electrophoresed through a $1 \%$ agarose, $16.7 \%$ formaldehyde gel and then transferred to a Hybond $\mathrm{N}+$ membrane (Amersham) in $5 \times$ SSC. The membrane was baked at $80^{\circ} \mathrm{C}$ for $10 \mathrm{~min}$ and exposed to UV light for $7 \mathrm{~s}$ in an Amersham UV crosslinker. The $1.2 \mathrm{~kb}$ human GnRHR cDNA fragment and a $\beta$-actin cDNA fragment were labeled using a Megaprime end-labeling kit (Amersham), for use as probes. Membranes were pre-hybridized for $2 \mathrm{~h}$ and then hybridized with the probe overnight at $42{ }^{\circ} \mathrm{C}$ in $20 \mathrm{mmol} / \mathrm{l}$ Pipes $\mathrm{pH} 6.5,0.8 \mathrm{~mol} / \mathrm{l} \mathrm{NaCl}, 50 \%$ formamide, $0.5 \%$ SDS, $100 \mu \mathrm{g} / \mathrm{ml}$ salmon sperm DNA, followed by washing (final wash $0.2 \times \mathrm{SSC}, 0.1 \%$ SDS, $60^{\circ} \mathrm{C}$ for $20 \mathrm{~min}$ ). Probed membranes were then analyzed on a Hewlett Packard Instant Imager gel scanner (Packard Instruments, MD, CT, USA) to quantify the amount of receptor and $\beta$-actin RNA.

\section{Receptor internalization}

Forty-eight hours after transfection, the cells were washed in ice-cold Buffer I and then incubated with 150000 c.p.m. ${ }^{125} \mathrm{I}-\mathrm{GnRHA}$ for $3 \mathrm{~h}$ on ice. The cells were then moved to a $37^{\circ} \mathrm{C}$ water bath and incubated for the indicated times to allow internalization, without removing the radiolabeled peptide from the medium. After the incubation, the cells were transferred to an ice bath and washed twice with cold PBS. Externally bound ligand was collected by a $10 \mathrm{~min}$ acid wash $(50 \mathrm{mmol} / \mathrm{l}$ acetic acid, $150 \mathrm{mmol} / \mathrm{l} \mathrm{NaCl}$ ), while the internalized ligand was measured by solubilizing with $0.1 \mathrm{~mol} / \mathrm{l}$ $\mathrm{NaOH}$

\section{Cell surface receptor stability}

Forty-eight hours after transfection, cells were incubated with or without cycloheximide in the absence of ligand, at $37^{\circ} \mathrm{C}$. At the indicated times, the cells were transferred to $4{ }^{\circ} \mathrm{C}$ and incubated with 100000 c.p.m. ${ }^{125} \mathrm{I}$-GnRHA for $3 \mathrm{~h}$. The cells were washed twice with cold PBS and the externally bound ligand was removed by a $10 \mathrm{~min}$ acid wash $(50 \mathrm{mmol} / \mathrm{l}$ acetic acid, $150 \mathrm{mmol} / \mathrm{l} \mathrm{NaCl})$.

\section{Data reduction}

Graphpad Prism (Graphpad Software, San Diego, CA, USA) was used for four-parameter non-linear curve fitting to estimate peptide concentrations required to stimulate half-maximal $\left(\mathrm{EC}_{50}\right)$ IP production and to half-maximally inhibit binding of radioligand $\left(\mathrm{IC}_{50}\right)$. LIGAND (26) was used to estimate the dissociation constant $\left(K_{\mathrm{d}}\right)$ and receptor numbers in the competition binding studies. Figures show representative experiments (unless stated otherwise), in which data points are the mean \pm s.D. of triplicate or duplicate determinations. The mean values were used to calculate the percentage wild type for each experiment. The average of the percentage wild type values obtained is shown \pm s.D. in Table 1 .

\section{Results}

\section{Effects of GnRHR mutations on IP production}

Point mutations were introduced separately at six positions of the GnRHR by site-directed mutagenesis: A261I and L266I in ICIII, F272L and F276Y in TMH VI and F309E and C317Y in TMH VII. Wild type and mutant receptors were screened for increased basal IP production in the absence of ligand, a feature of constitutively active receptors. The basal IP production in the absence of transfected DNA, as well as for wild type and mutant receptors was in the range 75130 c.p.m, showing that neither the wild type nor any of the mutant GnRHRs was constitutively active.

Although the F272L GnRHR did not display an increase in basal IP production, the dose-response curve for agonist-induced IP production was left-shifted with respect to the wild type, showing a 3-fold increase in potency (Fig. 1).

\section{Ligand binding characteristics of the F272L GnRHR}

In the TSHR, mutation of Phe at position 631 to Leu caused the receptor to be constitutively active (21). Alignment of the TMHs revealed that Phe-272 of the human GnRHR is the equivalent of Phe-631 of the TSHR. The mutation F272L did not increase basal IP production above that of the wild type receptor. However, the binding data showed that this mutant had two to four times more specific binding than the wild type receptor (Figs. 2 and 3).

Homologous competition binding studies with GnRHA in whole cell binding assays show that the F272L GnRHR has the same affinity $\left(K_{\mathrm{d}}=5.6 \pm\right.$ $0.9 \mathrm{nmol} / \mathrm{l})$ as the wild type $\left(K_{\mathrm{d}}=4.5 \pm 1.1 \mathrm{nmol} / \mathrm{l}\right)$ (Table 1). Heterologous competition binding in whole cells was performed using ${ }^{125} \mathrm{I}-\mathrm{GnRHA}$ and unlabeled GnRH. The affinity of the F272L GnRHR for $\mathrm{GnRH}\left(K_{\mathrm{d}}=3.9 \pm 0.6 \mathrm{nmol} / \mathrm{l}\right)$ was unchanged from that of the wild type receptor $\left(K_{\mathrm{d}}=4.4 \pm 1.9 \mathrm{nmol} / \mathrm{l}\right)$. In homologous antagonist competition binding in whole cells, the same affinities for the F272L $\left(K_{\mathrm{d}}=\right.$ $4.0 \pm 1.5 \mathrm{nmol} / \mathrm{l})$ and wild type GnRHRs $\left(K_{\mathrm{d}}=3.6 \pm\right.$ $1.1 \mathrm{nmol} / \mathrm{l})$ were obtained. In all three competition assays, the F272L GnRHR showed several-fold more receptor expressed on the cell surface than the wild type receptor (Table 1 ).

Binding experiments were also performed on total cell membranes with displacement by GnRH, GnRHA and Ant26, for both wild type and the F272L mutant GnRHR. These results showed a similar increase in receptor numbers for the mutant receptor relative to wild type, with unchanged affinity for the ligands 
(Table 1). The F272L mutant was back-mutated to the wild type sequence and the back-mutated construct was shown to have wild type binding (data not shown), showing that the mutation at the single Phe-272 amino acid residue in the construct was responsible for the increase in F272L GnRHR expression.

Two F272L GnRHR constructs with different codons for Leu resulted in similar increases in specific binding compared with the wild type receptor (F272L$1=341 \%$, and $\mathrm{F} 272 \mathrm{~L}-2=376 \%$ ).

\section{Radioligand binding of mutant GnRHRs with different substitutions at Phe-272 and Phe-276}

To examine the chemical basis of the increased receptor numbers, Phe-272 was mutated to Ala, Glu, Lys and Tyr. Binding assays showed that only the F272L GnRHR had an increased receptor number (Fig. 4). When Phe272 was mutated to a positively or negatively charged amino acid, no binding was detected (Fig. 4). These mutants also did not produce IPs in response to agonist stimulation (data not shown). When Ala or Tyr was substituted at position 272, the resulting mutant receptors had decreased specific binding, but had similar affinities for agonist ligand, compared with the wild type (Fig. 4, Table 1 and not shown).

Phe-276, one turn of a putative alpha helix after Phe272 in TMH VI, was mutated to Leu to see if the effect observed for the F272L GnRHR was dependent on the Phe position within the TMH. The F276L mutant had no binding which could be detected (Fig. 4) or agoniststimulated IP production (data not shown). The F276Y GnRHR mutant had the same binding (Fig. 4) and IP production characteristics (data not shown) as the F272Y mutant.

\section{Northern blot analysis}

To determine whether the increased expression of the F272L GnRHR relative to the wild type receptor was caused by an increase in GnRHR mRNA levels, RNA was extracted from COS- 1 cells transfected with the F272L GnRHR or wild type receptor cDNA. Similar amounts of RNA were analyzed by Northern blotting, using the fulllength GnRHR cDNA as a radiolabeled probe (Fig. 5). The membrane was stripped and re-probed with a radiolabeled $\beta$-actin probe. Relative levels of GnRHR mRNA were quantified by measuring the radioactive signal in the GnRHR band as a ratio of the signal in the $\beta$-actin band. For two independent experiments, the ratio of wild type GnRHR mRNA relative to F272L GnRHR mRNA, normalized for $\beta$-actin, was $1.25 \pm 0.23$.

\section{Receptor internalization}

The increased cell surface receptor numbers of the F272L GnRHR relative to wild type could be due to a decrease in the rate of receptor internalization from the 


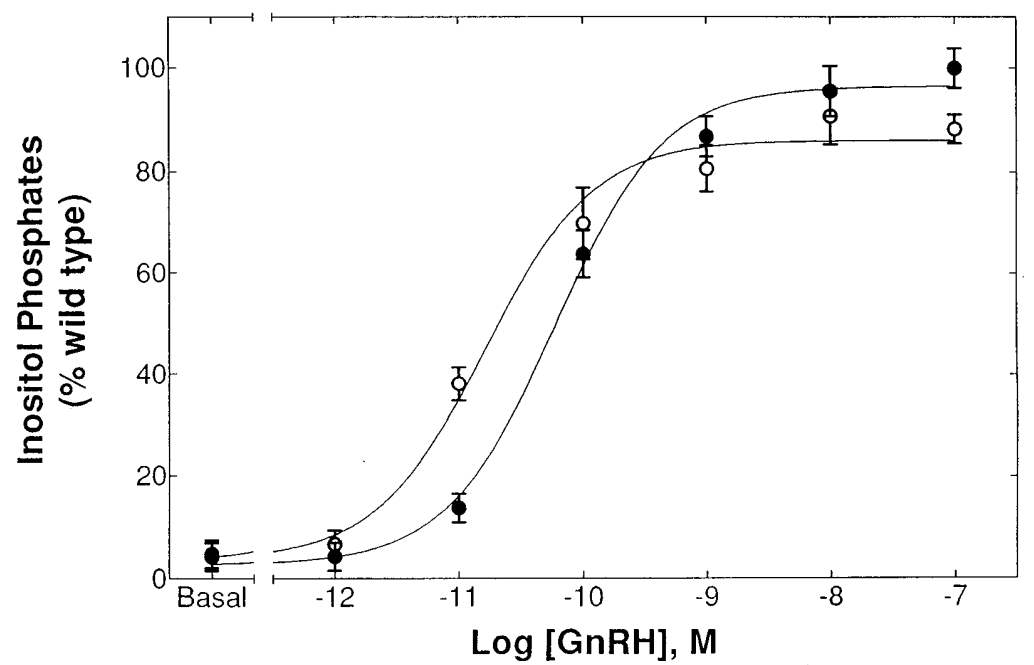

Figure $1 \mathrm{IP}$ production in response to $\mathrm{GnRH}$ for the wild type $(\bullet)$ and the F272L mutant $(\mathrm{O})$. $\left[{ }^{3} \mathrm{H}\right]$ Inositol-labeled transfected COS-1 cells were incubated for $1 \mathrm{~h}$ with the indicated concentrations of $\mathrm{GnRH}$. $\mathrm{EC}_{50}$ values for wild type and F272L GnRHRs were $60.0 \pm 5.6$ and $16.3 \pm 4.1 \mathrm{pmol} / \mathrm{l}$ respectively. The absolute values for wild type basal and agonist-stimulated maximal IP production were $112 \pm 12$ and $7210 \pm 1861$ c.p.m. respectively. Data are means \pm S.D. of triplicate determinations, and are normalized to percentage of wild type data.

cell surface. To investigate this possibility, cells transfected with wild type or F272L GnRHR were incubated with ${ }^{125} \mathrm{I}$-GnRHA on ice and then transferred to $37^{\circ} \mathrm{C}$ to allow internalization. Internalization was stopped by placing the cells on ice and washing with cold PBS. An acid wash was used to remove cell surface ligand, and internalized ligand was measured after solubilizing the cells in $\mathrm{NaOH}$. Agonist-induced internalization showed that the F272L mutant internalized at the same rate as the wild type (Fig. 6). More receptors were measured both externally and internally for the mutant than for the wild type. This is consistent with the presence of more total receptors for the mutant than the wild type, in the absence of a decreased rate of internalization.

\section{Cell surface receptor stability}

The increase in receptor numbers of the F272L GnRHR relative to wild type could be due to an increased stability of the unliganded mutant receptor on the cell surface. Receptor binding as a function of time was measured in the absence or presence of the protein synthesis inhibitor cycloheximide. Cycloheximide caused a similar fractional decrease in cell surface receptor numbers in both

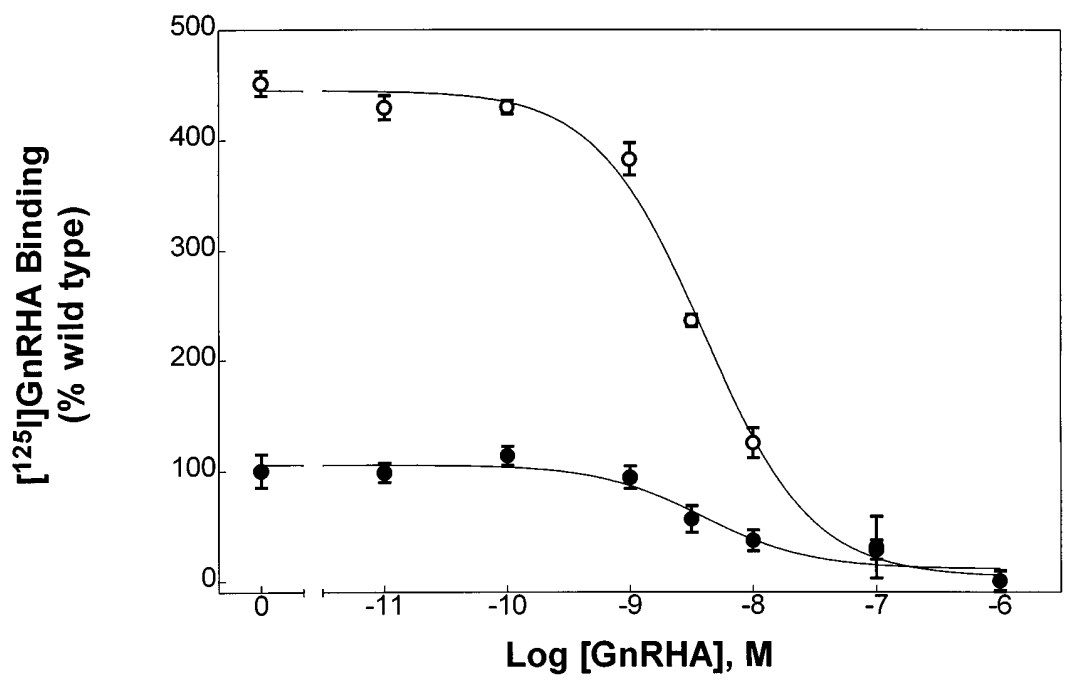

Figure 2 Agonist binding displacement curves for the wild type $(\bullet)$ and F272L mutant $(O)$ GnRHR. Transfected COS-1 cells were incubated with ${ }^{125} \mathrm{I}-\mathrm{GnRHA}$ and indicated concentrations of unlabeled $\mathrm{GnRHA}$ at $4{ }^{\circ} \mathrm{C}$ for $3 \mathrm{~h}$. Data are means \pm S.D. of triplicate determinations, and are normalized to percentage of wild type data. A representative experiment is shown. 


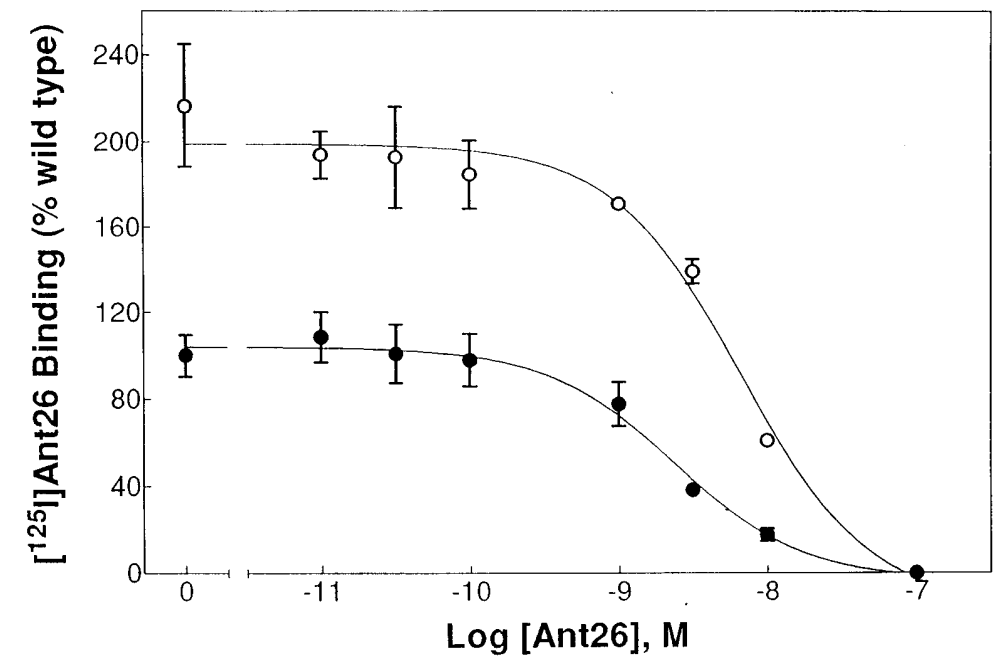

Figure 3 Antagonist binding displacement curves for wild type $(\bullet)$ and F272L $(O)$ GnRHR. Membranes of transfected COS-1 cells were incubated for $30 \mathrm{~min}$ at $37^{\circ} \mathrm{C}$ with ${ }^{125} \mathrm{I}-$ Ant26 and indicated concentrations of unlabeled Ant26. Data are means \pm S.D. of triplicate determinations, and are representative of three similar experiments.

receptors (Fig. 7), suggesting that the F272L GnRHR has a half-life on the cell surface similar to that of the wild type receptor.

\section{Discussion}

Six sites were mutated in the human GnRHR, corresponding to positions of amino acids leading to constitutive activity when mutated in other $G_{i}, G_{s}$ or $\mathrm{G}_{\mathrm{q}} / \mathrm{G}_{11}$-coupled GPCRs. The failure of the GnRHR to be constitutively activated by any of the mutations in this study indicates that a common mechanism of activation does not exist for all GPCRs. This, together with the low intrinsic basal activity of the GnRHR relative to that of the TSHR, indicates that the equilibrium between the active and inactive GnRHR strongly favors the inactive form when compared with certain other GPCRs like the TSHR.

Mutation of a Phe at position 631 in TMH VI to a Leu in the TSHR causes the receptor to be constitutively active (21). The F631L mutant showed an increase in basal cAMP production, but binding of ${ }^{125}$ I-labeled TSH was unchanged compared with the wild type. When the TMHs of the TSHR are aligned with the human GnRHR, Phe-272 is the equivalent of Phe-631. The F272L mutant exhibited a similar maximal IP response to GnRH stimulation and unchanged affinities for $\mathrm{GnRH}$, GnRHA and Ant26 (Figs 1, 2 and 3, Table 1) compared

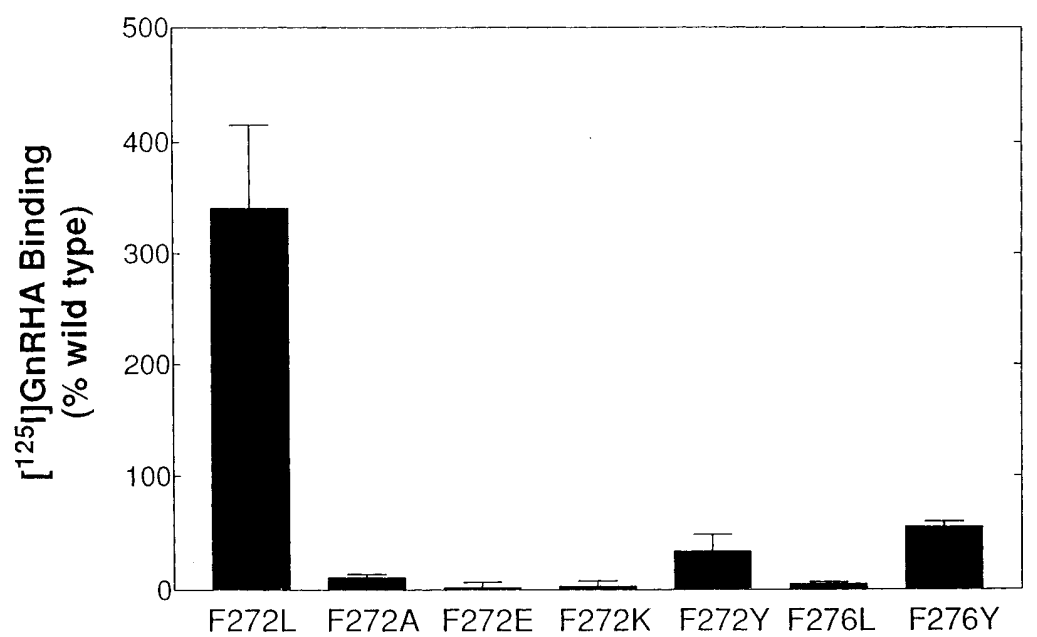

Figure 4 Specific binding of the wild type and mutant Phe-272 and Phe-276 receptors. ${ }^{125}$ I-GnRHA was used to determine the specific binding of various mutant receptors. Data are presented as percentage of the wild type specific binding. Values are means \pm S.D. of at least three experiments. 


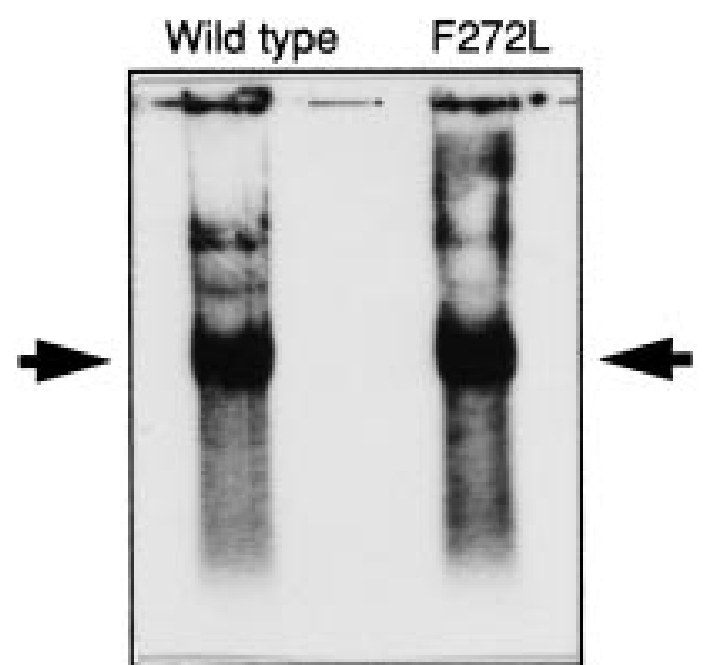

Figure 5 Northern blot of wild type and F272L mutant GnRHR RNA (shown by the arrows) in transfected COS-1 cells. Total RNA was isolated from COS-1 cells transfected with wild type and F272L mutant GnRHRs, electrophoresed on an agarose/formaldehyde gel, transferred to nitrocellulose and hybridized with radiolabeled GnRHR or $\beta$-actin cDNA. An autoradiogram of the membrane is shown. The ratio of GnRHR to $\beta$-actin signal for wild type was 0.54 and for F272L, 0.39. with the wild type GnRHR. An unexpected finding was the marked overexpression of the F272L GnRHR mutant. Results from both whole cell and a membrane binding assay (Table 1) show that the receptor number is increased both extracellularly (whole cell assay) and intracellularly (total membrane binding). The affinities for GnRH, GnRH agonist and GnRH antagonist were indistinguishable in the wild type and F272L mutant receptors. The consistently higher affinity of both the mutant and wild type receptor for all the ligands in the total membrane assay compared with the whole cell assay most likely reflects the low salt concentration in the membrane binding assay compared with the physiological medium used with whole cell binding (27). The lower $\mathrm{EC}_{50}$ for IP production in response to GnRH obtained for the F272L mutant compared with wild type GnRHR is consistent with an increase in receptor numbers on the cell surface, in the presence of a receptor reserve (Fig. 1).

We have used binding data to calculate receptor numbers on the cell surface and in cell membranes, as a measure of GnRHR protein expression, since we have not to date been able to raise antibodies to the GnRHR which recognize the expressed receptor on the cell

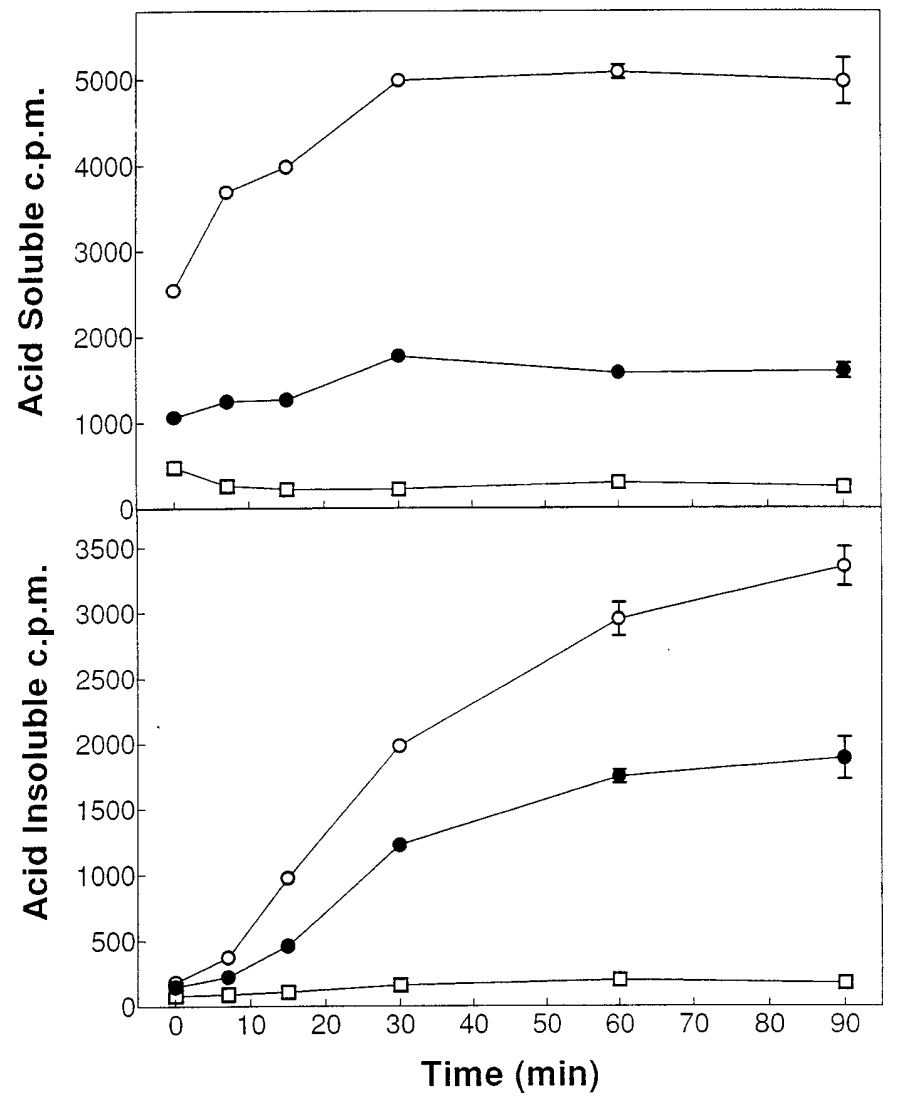

Figure 6 Agonist-induced internalization of wild type and F272L receptors. Cell surface receptors were measured for the wild type $(\bullet)$ and F272L GnRHR (O) by removal of ${ }^{125} \mathrm{I}-\mathrm{GnRHA}$ with an acid wash (upper panel). The amount of internalized receptors was determined by solubilizing the cells with $0.1 \mathrm{~mol} / / \mathrm{NaOH}$ (lower panel). Untransfected COS-1 cells ( $\square$ ) were used as a control. Data are means \pm s.D. of duplicate determinations from four independent experiments. 


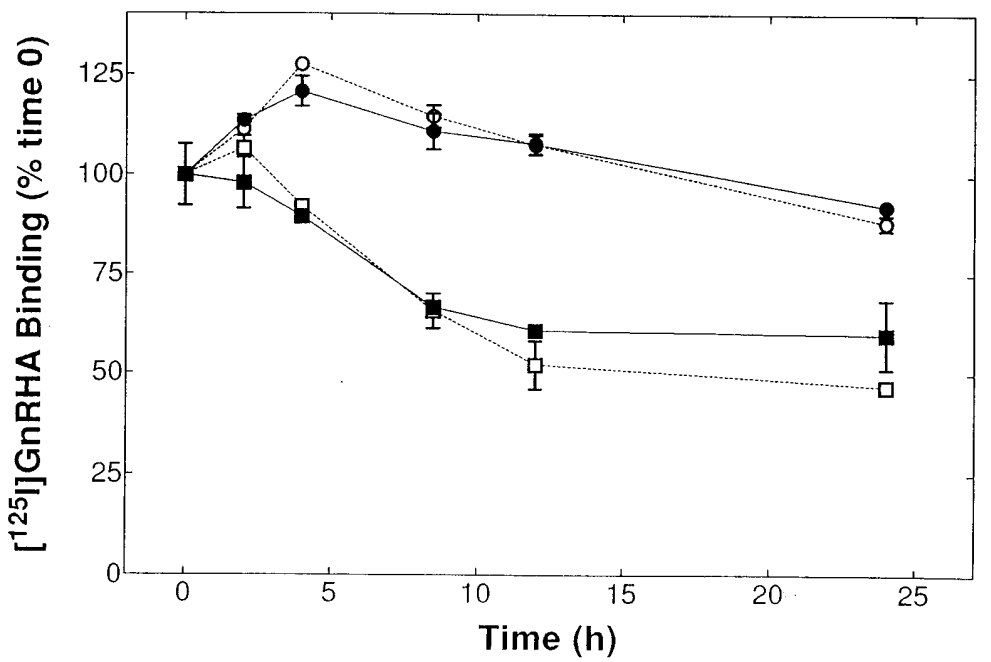

Figure 7 Measurement of wild type (filled symbols) and F272L mutant (open symbols) receptor stability on the cell surface. Radioligand binding was measured in the presence (squares) and absence (circles) of the protein synthesis inhibitor cycloheximide. The data are presented as a percentage of the zero time point, which was taken as the time when cycloheximide was added.

surface, and FLAG and HA epitope tagged receptor does not display wild type characteristics (A Katz \& RP Millar, unpublished observations).

In order to examine the role of the amino acid side chain in the increased expression, we investigated the effects of other substitutions at position 272 of the GnRHR by constructing the mutants F272Y, F272A, $\mathrm{F} 272 \mathrm{~K}$ and $\mathrm{F} 272 \mathrm{E}$. The non-conservative mutations to Lys and Glu resulted in non-functional receptors (Fig. 4 and data not shown). The conservative F272Y GnRHR had characteristics similar to those of the wild type receptor. The characteristics of the F272A GnRHR (20\% total specific binding compared with wild type) most likely reflect a pronounced decrease in receptor expression. Introduction of hydrogen bonding residues or a small hydrophobic residue all decreased receptor numbers. Thus a large hydrophobic residue is required in position 272 for high receptor expression.

Other underlying mechanisms which could account for overexpression of the F272L GnRHR were investigated. Increased protein expression could be due to increased mRNA synthesis or stability. Northern blot analysis of the F272L and wild type GnRHR RNA expressed in COS-1 cells revealed no differences in steady-state mRNA levels, indicating that the difference in the receptor expression is due to post-transcriptional events (Fig. 5).

Since two F272L GnRHR constructs with different codons for Leu resulted in similar increases in specific binding compared with the wild type receptor, secondary structure differences during translation are unlikely to be the cause of overexpression. However, it is possible that translation of the F272L GnRHR mRNA is more efficient than that for the wild type receptor, for reasons other than secondary structure of the nucleic acids.
However, we did not detect any difference in the amount of translated receptor protein for the F272L GnRHR compared with wild type receptor in an in vitro translation assay (data not shown).

A decreased rate of receptor internalization from the cell surface could also account for increased cell surface receptor numbers. However, we showed that a decreased rate of agonist-induced internalization is not responsible for the increased receptor numbers as the F272L GnRHR does not internalize at a slower rate than the wild type (Fig. 6). There was more radiolabeled ligand both externally and internally for the F272L GnRHR compared with the wild type receptor. This indicates that the F272L mutant has an increased receptor number throughout the cell, compared with the wild type. This is substantiated by the membrane binding assays, which also showed the increased receptor numbers for the mutant receptor. The data suggest that the Leu-272 mutation increases the rate of translation, membrane insertion or folding of the receptor protein, such that the rate of delivery to the cell surface is increased.

The majority of point mutations in the TMHs of the GnRHR and other GPCRs decrease receptor expression on the cell surface, possibly due to folding defects (JS Davidson, CA Flanagan, JP Hapgood, RP Millar \& DB Myburgh, unpublished observations and reference 28). Thus, it is unusual to find a mutation in the GnRHR which results in an increased receptor expression. The characteristics of the F272Y GnRHR are similar to wild type receptor and indicate a requirement for an aromatic or large lipophilic residue at this position for wild type expression, while mutations to residues with acidic, basic, hydrophilic or small hydrophobic side chains decrease expression, possibly by disruption of TMH 
VI, or of important interhelical interactions. One turn above the Phe-272 in the putative alpha helix of TMH VI is another Phe (Phe-276). We considered it might be instructive to determine whether mutation of this Phe would have a similar effect on expression. The F276L mutant, in contrast to the F272L mutant, was nonfunctional. However, mutation to Tyr (F276Y) resulted in wild type characteristics as shown for F272Y. These results indicate that while the aromatic character of Phe residues in TMH VI is important for wild type receptor expression and function, the effects of mutation of Phe to Leu on overexpression are position specific.

Since natural mutation of Phe-272 to the higherexpressing and fully functional F272L would require only one nucleotide change, the question might be posed as to why this mutation has not occurred naturally. Since the GnRHR gene is highly regulated by GnRH itself and by gonadal steroids and peptides (29), selective forces may have favored low basal expression and selected against more highly expressing sequences.

\section{Acknowledgements}

This work was supported by grants from the Foundation for Research Development (R P M and J P H), the South African Medical Research Council (RPM), Fogarty International (R P M) and by the University of Cape Town and the Harry Crossley Foundation (R P M).

\section{References}

1 Tsutsumi M, Zhou W, Millar RP, Mellon PL, Roberts JL, Flanagan CA, Dong K. Gillo B \& Sealfon SC. Cloning and functional expression of a mouse gonadotropin-releasing hormone receptor. Molecular Endocrinology $199261163-1169$.

2 Reinhart J, Mertz LM \& Catt KJ. Molecular cloning and expression of cDNA encoding the murine gonadotropin-releasing hormone receptor. Journal of Biological Chemistry 199226721281 21284.

3 Kakar SS, Musgrove LC, Devor DC, Sellers JC \& Neill JD. Cloning, sequencing, and expression of human gonadotropin releasing hormone (GnRH) receptor. Biochemical and Biophysical Research Communications 1992189 289-295.

4 Chi L, Zhou W, Prikhozhan A, Flanagan CA, Davidson JS, Golembo M, Illing N, Millar RP \& Sealfon SC. Cloning and characterization of the human GnRH receptor. Molecular and Cellular Endocrinology 199391 R1-R6.

5 Hsieh KP \& Martin TFJ. Thyrotropin-releasing hormone and gonadotropin-releasing hormone receptors activate phospholipase $\mathrm{C}$ by coupling to the guanosine triphosphate-binding proteins $\mathrm{G}_{\mathrm{q}}$ and $\mathrm{G}_{11}$. Molecular Endocrinology $199261673-$ 1681.

6 Dohlman HG, Thorner J, Caron MG \& Lefkowitz RJ. Model systems for the study of seven-transmembrane-segment receptors. Annual Review of Biochemistry $199160653-688$.

7 Baldwin JM. The probable arrangement of the helices in G protein-coupled receptors. EMBO Journal $1993121693-$ 1703.

8 Clapham DE. Mutations in G protein-linked receptors: novel insights on disease. Cell 199375 1237-1239.
9 Parma J, Duprez L, Van Sande J, Cochaux P, Gervy C, Mockel J, Dumont J \& Vassart G. Somatic mutations in the thyrotropin receptor gene cause hyperfunctioning thyroid adenomas. Nature $1993365649-651$.

10 Robbins LS, Nadeau JH, Johnson KR, Kelly MA, Roselli-Rehfuss L, Baack E, Mountjoy KG \& Cone RD. Pigmentation phenotypes of variant extension locus alleles result from point mutations that alter MSH receptor function. Cell 199372 827-834.

11 Shenker A, Laue L, Kosugi S, Merendino JJ Jr, Minegishi T \& Cutler GB Jr. A constitutively activating mutation of the luteinizing hormone receptor in familial male precocious puberty. Nature $1993365652-654$.

12 Paschke R, Tonacchera M, Van Sande J, Parma J \& Vassart G. Identification and functional characterization of two new somatic mutations causing constitutive activation of the thyrotropin receptor in hyperfunctioning autonomous adenomas of the thyroid. Journal of Clinical Endocrinology and Metabolism 1994 79 1785-1789.

13 Pollak MR, Brown EM, Estep HL, McLaine PN, Kifor O, Park J, Hebert SC, Seidman CE \& Seidman JG. Autosomal dominant hypocalcaemia caused by a $\mathrm{Ca}^{2+}$-sensing receptor gene mutation. Nature Genetics 19948 303-307.

14 Parma J, Van Sande J, Swillens MT, Dumont J \& Vassart G. Somatic mutations causing constitutive activity of the thyrotropin receptor are the major cause of hyperfunctioning thyroid adenomas: identification of additional mutations activating both the cyclic adenosine $3^{\prime}, 5^{\prime}$-monophosphate and inositol phosphate-Ca ${ }^{2+}$ cascades. Molecular Endocrinology 19959 725733.

15 Latronico AC, Anasti J, Arnhold JP, Mendonca BB, Domenice S, Albano MC, Zachman K, Wajchenberg BL \& Tsigos C. A novel mutation of the luteinizing hormone receptor gene causing male gonadotropin-independent precocious puberty. Journal of Clinical Endocrinology and Metabolism $1995 \mathbf{8 0}$ 2490-2494.

16 Dryja TP, Berson EL, Rao VR \& Oprian DD. Heterozygous missense mutation in the rhodopsin gene as a cause of congenital stationary night blindness. Nature Genetics $19934280-283$.

17 Duprez L, Parma J, Van Sande J, Allegeier A, Leclère J, Schvartz C, Delisle MJ, Decoulx M, Orgiazzi J, Dumont JE \& Vassart G. Germline mutations in the thyrotropin receptor gene cause nonautoimmune autosomal dominant hyperthyroidism. Nature Genetics 19947 396-401.

18 Boone C, Davis NG \& Sprague GF Jr. Mutations that alter the third cytoplasmic loop of the a-factor receptor lead to a constitutive and hypersensitive phenotype. Proceedings of the National Academy of Sciences of the USA $1993909921-$ 9925.

19 Kjelsberg MA, Cotecchia S, Ostrowski J, Caron MG \& Lefkowitz RJ. Constitutive activation of the alpha $1 \mathrm{~B}$-adrenergic receptor by all amino acid substitutions at a single site. Evidence for a region which constrains receptor activation. Journal of Biological Chemistry 1992267 1430-1433.

20 Ren Q, Kurose H, Lefkowitz RJ \& Cotecchia S. Constitutively active mutants of the alpha 2-adrenergic receptor. Journal of Biological Chemistry 1993268 16483-16487.

21 Kopp P, Van Sande J, Parma J, Duprez L, Gerber H, Joss E, Jameson JL, Dumont JE \& Vassart G. Brief report: congenital hyperthyroidism caused by a mutation in the thyrotropin-receptor gene. New England Journal of Medicine 1995332 150-154.

22 Kunkel TA, Bebenek K \& McClary J. Efficient site-directed mutagenesis using uracil-containing DNA. Methods in Enzymology 1991204 125-139.

23 Keown WA, Campbell CR \& Kucherlapati RS. Methods for introducing DNA into mammalian cells. Methods in Enzymology $1990185527-537$.

24 Davidson JS, Wakefield IK, Sohnius U, van der Merwe PA \& Millar RP. A novel extracellular nucleotide receptor coupled to phosphoinositidase-C in pituitary cells. Endocrinology 1990126 80-87. 
25 Chomczynski P \& Sacchi N. Single-step method of RNA isolation by acid guanidinium thiocyanate-phenol-chloroform extraction. Analytical Biochemistry 1987162 156-159.

26 Munson PJ \& Rodbard D. LIGAND: a versatile computerized approach for characterization of ligand-binding systems. Analytical Biochemistry 1980107 220-239.

27 Wormald PJ, Eidne KA \& Millar RP. Gonadotropin-releasing hormone receptors in human pituitary: ligand structural requirements, molecular size, and cationic effects. Journal of Clinical Endocrinology and Metabolism 198561 1190-1194.
28 Kaushal S \& Khorana HG. Structure and function in rhodopsin. 7. Point mutations associated with autosomal dominant retinitis pigmentosa. Biochemistry 199433 6121-6128.

29 Millar R. Multiple regulatory elements in the human GnRH receptor gene. European Journal of Endocrinology $1997137118-$ 119 .

Received 19 February 1998

Accepted 19 May 1998 